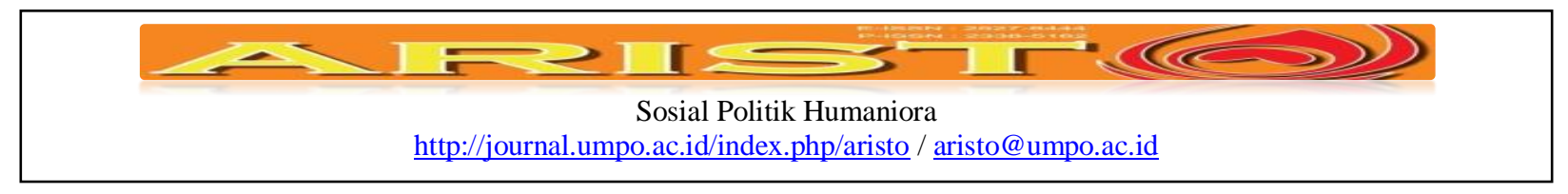

\title{
Model Program Pemberdayaan Masyarakat Desa Berbasis Komunitas
}

\author{
Yusuf Adam Hilman \\ Prodi Ilmu Pemerintahan, FISIP \\ Universitas Muhammadiyah Ponorogo \\ 545471adamongis@gmail.com / adamhilman@umpo.ac.id \\ Elok Putri Nimasari \\ Prodi Teknik Informatika, Fakultas Teknik \\ Universitas Muhammadiyah Ponorogo \\ elokputrinimasari@gmail.com
}

\begin{abstract}
This study examines the issue of community empowerment, which is considered to be a solution problem of poverty, which is more interesting when the community of "Janda" becomes an important object. This research focuses on the study of community-based community empowerment model in Janda village. Purpose is able to measure the effectiveness and also the ideal form of community empowerment program model in the village of Janda, Dadapan Village, Balong District, Ponorogo Regency. The research are method qualitative descriptive approach, with object in research is the people members, especially mothers who berrstatus "widow" in the Dadapan Village, Balong District, Ponorogo Regency.. Activities include 1). Training of processed food from the existing agricultural potential, 2). Make a kitchen granary from the land around the community. 3). Train the art activities of mothers who are "Janda". From concluded this research is community empowerment activities in Dadapan Village, Balong District, Ponorogo Regency, which have been done are very focused on "Janda", so that the activity is expected to contribute, to the life of those who is distressed or increase the independence of the family, with this activity, economical but psychologically they will be motivated to become a powerful individual.
\end{abstract}

Keyword: Community, Janda, Community Empowerment.

\begin{abstract}
Abstrak
Penelitian ini mengkaji persoalan pemberdayaan masyarakat yang dianggap menjadi penyelesaian bagi persoalan kemiskinan, yang lebih menarik adalah ketika komunitas "janda” menjadi obyek yang penting. Penelitian ini di fokuskan kajian terhadap model pemberdayaan masyarakat berbasis Komunitas di desa Janda. Tujuannya supaya bisa mengukur efektifitas dan juga bentuk ideal dari model program pemberdayaan masyarakat di desa Janda Dadapan, Kecamatan Balong, Kabupaten Ponorogo. Metode penelitiannya menggunakan pendekatan deskriptif kualitatif, dengan obyek penelitian adalah anggota masyarkaat khususnya ibu - ibu yang berrstatus "janda” di Desa Dadapan Kecamatan Balong Kabupaten Ponorogo. Kegiatannya meliputi 1). Pelatihan pembuatan olahan hasil pangan dari potensi pertanian yang ada, 2). Membuat lumbung dapur dari lahan di sekitar masyarakat. 3). Melatih kegiatan berkesenian ibu - ibu yang berstatus "Janda”. Dari hasil tersebut dapat di simpulkan bahwa Kegiatan pemberdayaan masyarakat di Desa Dadapan, yang telah dilakukan sangat fokus terhadap “janda”, sehingga kegiatan tersebut diharapkan bisa memberikan kontribusi, terhadap kehidupan mereka yang kesusahan dan meningkatkan kemandirian keluarga, dengan adanya kegiatan ini, tidak hanya secara ekonomis namun secara psikologis mereka akan termotivasi untuk menjadi individu yang berdaya.
\end{abstract}

Kata Kunci: Komunitas, Janda, Pemberdayaan Masyarakat

\begin{tabular}{|ll}
\hline Submite & $:$ 10 September 2017 \\
Review & $:$ 15 November 2017 \\
Accepted & $:$ 01 Januari 2018 \\
Surel Corespondensi & $:$ darwisnasution@gmail.com
\end{tabular}

Yusuf Adam Hilman, Elok Putri Nimasari. Model Program Pemberdayaan Masyarakat Desa Berbasis Komunitas./ 04/ Vol. 6. No. 1. Tahun 2018 


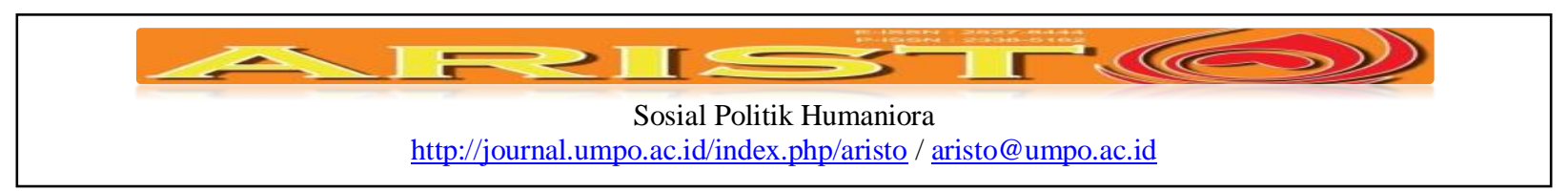

\section{Pendahuluan}

Persoalan Janda, bukan hanya permasalahan stigma yang berkembang di Masyarakat, terkait status janda dianggap oleh sebagian masyarakat bercitra negatif, tabu, dan juga diremehkan oleh masyarakat, karena dianggap hina, namun status janda bukanlah menjadi halangan bagi seseorang untuk memilih menjadi Janda dengan cara bercerai karena berbagai pilihan.

The stigmatisation of widows and divorcees that is elaborated in articles in this issue can be contextualised in a variety of ways. Here I use mainly anthropological literature on societies in Indonesia to sketch two different sorts of context that help us to make sense of the stigma: firstly, stigma attached to women in Indonesia for a variety of conditions to do with marriage and sex, and secondly, attitudes towards divorce in diverse cultural contexts in Indonesia and shifts in these since the 1950s. The role of the New Order state in transforming attitudes towards divorce is singular. Through its mass schooling programmes, family and gender ideology and general development policies, it was influential in constructing new understandings of marriage and divorce, and through legislation and regulation directly instrumental in making divorce much more difficult for women. These two contexts show that the stigmatisation of janda resonates with other stigmas applied to women who do not or cannot measure up to the ideal of woman-hood in Indonesia: the properly married, fertile ibu (mother/wife). It gets traction from changing social morés which now denigrate divorce and make women who seek divorce feel ashamed. In other words, the stigma works because it uses the cultural resources at hand: janda are easily constructed as women of ill repute who contrast with the virtuous ibu who have husbands. Of course I could have contextualised the stigma using other approaches - for instance, socio-economic, legal or historical approaches. ${ }^{1}$

Pilihan menjadi janda merupakan konsekuensi logis, dari berbagai fenomena yang berawal atau berangkat dari, proses pernikahan yang dianggap tidak dipersiapkan secara optimal, misalnya kesiapan dari beberapa aspek, seperti: kematangan psikologis, kemapanan finansial, kematangan usia pernikahan, dan juga kesiapan pasangan dalam mengatasi persoalan kehidupan. Provinsi Jawa Timur merupakan daerah dengan persebaran angka perceraian paling tinggi di Indonesia ${ }^{2}$.

Kondisi tersebut pada akhirnya melahirkan kawasan penghasil janda atau lumbung penyumbang angka perceraian yang tinggi, misalnya Kabupaten Ponorogo, dalam pemberitaan

\footnotetext{
${ }^{1}$ Parker, Lyn, The theory and context of the stigmatisation of widows and divorcees (janda) in Indonesia. Indones Malay World. 2015;44(128):7-26. doi:10.1080/13639811.2015.1100863.

${ }^{2}$ Diakses dari http://bdkpadang.kemenag.go.id/index.php?option=com_content\&view=article\&id=537:persiapan-perkawinan-ditinjaudari-segi-biologis-dan-psikologis\&catid=41:top-headlines diakses 08 Desember 2018.
}

Yusuf Adam Hilman, Elok Putri Nimasari. Model Program Pemberdayaan Masyarakat Desa Berbasis Komunitas./ 04/ Vol. 6. No. 1. Tahun 2018 


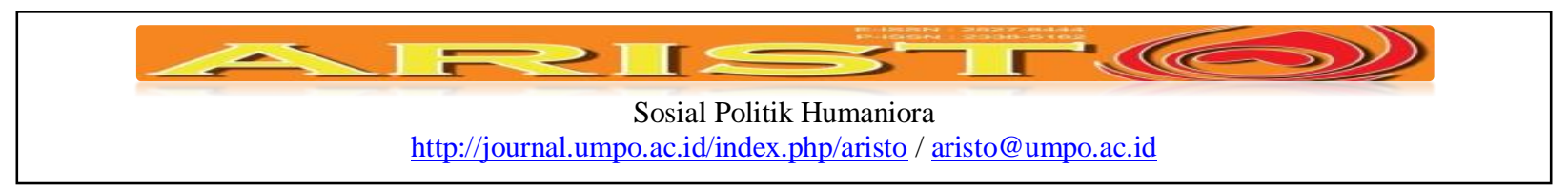

beberapa minggu terakhir pada harian radar Ponorogo, ada satu wilayah tepatnya di Desa Dadapan, Kecamatan Balong, tercatat hampir 90 Persen masyarakatnya berstatus janda, baik cerai mati ataupun cerai hidup. Hal ini sangat merisaukan hati, bagaimana kondisi tersebut bisa terjadi, sebenarnya di desa janda tersebut ada mitologi terkait "mbok rondho", yang dianggap oleh masyarakat sekitar tersebut sebagai cikal bakal, kenapa wilayah tersebut memiliki jumlah Janda yang snagat banyak, namun kepala desa Dadapan, menegaskan bahwa penyebab perceraian atau beralihnya status dari nikah ke cerai, adalah karena banyaknya TKW yang sepulangnya dari merantau kemudian mengajukan gugatan cerai terhadap suaminya, hal inilah yang menurut Rusmiatin kepala desa Dadapan menjadi sebab utama. ${ }^{3}$

Berkaca terhadap persoalan yang ada di Desa Dadapan Kecamatan Balong tentang fenomena kampung janda, membuat kami berfikir ulang, terkait upaya apa yang sudah dilakukan atau tengah dilakukan oleh steakholder maupun penggiat program - program pemberdayaan di wilayah tersebut, selain itu bagaimanakah ketahanan ekonomi serta kemandirian personal para janda, dalam upaya untuk mempertahankan kehidupan tanpa sosok kepala keluarga, sehingga kami ingin mengetahui bagaimanakah model pemberdayaanyang telah dilakukan, dan sejauhmana efektifitas progam - program tersebut.

Muktasam mengutarakan bahwa bahwa proses pembangunan di wilayah pedesaan khususnya terkait dnegan program pengentasan kemiskinan yang ada di Asia dan Afrika, bahwa terdapat beberapa faktor-faktor yang menyebabkan gagalnya program pengentasan kemiskinan diantaranya: a). lebih menggunakan pendekatan 'target' dan 'top-down'; b).. Tidak memanfaatkan nilai - nilai lokal dan lebih bersifat formalitas atau bias 'outsiders'; c). rendahnya partisipasi; d). memanfaatkan pendekatan yang tidak holistik; dan e). Ilusi investasi. ${ }^{4}$

Dalam penelitian iniada ebberapa persoalan yang ingin di bahas yaitu: 1).Apa saja Program - program pemberdayaan yang dilakukan di Kampung Janda, 2). Sejauhmana Efektifitas Program pemberdayaan yang dilakukan di Kampung Janda, 3). Bagiamanakah Model yang tepat terkait dengan program pemberdayaan berbasis komunitas pada masyarakat yang berstatus Janda,

\footnotetext{
${ }^{3}$ Diakses dari Harian Ponorogopos edisi. No. 725 Tahun XV, 21 - 27 April 2016 pada 27 April 2016.

${ }^{4}$ Hadi AP, Negeri DD. Tinjauan Terhadap Berbagai Program Pemberdayaan Masyarakat di Indonesia. 2001.
}

Yusuf Adam Hilman, Elok Putri Nimasari. Model Program Pemberdayaan Masyarakat Desa Berbasis Komunitas./ 04/ Vol. 6. No. 1. Tahun 2018 


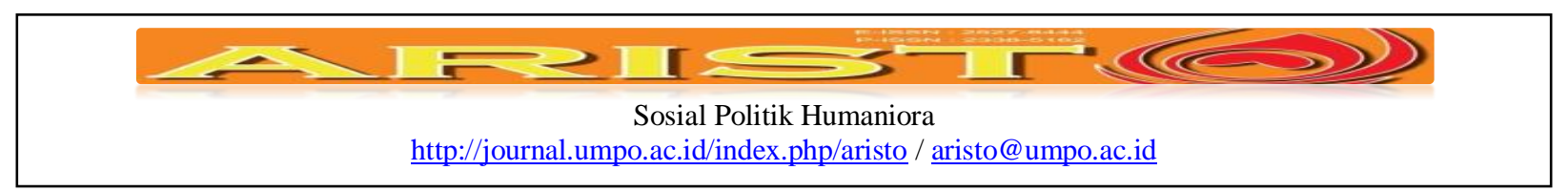

\section{Metode Penelitian / Kajian Pustaka}

Pendekatan penelitian ini memakai pendekatan kritis, dengan jenis penelitian kualitatif deskriptif, hal ini bertujuan untuk menganalisis program pemberdayaan masyarakat berbasis komunitas, sehingga peneliti bisa membuat sebuah evaluasi dari model Penelitian ini. Riset kualitatif berusaha untuk mengungkap berbagai fenomena serta realitas sosial, yang ada di masyarakat. Teori-teori sosial seperti sosiologi secara empiris biasanya dikembangkan melalui pendekatan kasus dan fenomena. Dengan demikian teori yang dihasilkan mendapatkan pijakan yang kuat pada realitas, bersifat kontekstual dan historis. Kualitatif riset dalam beberapa praktiknya memberikan banyak bagi dialog-dialog ilmiah, tentunya dengan pendalaman fenomena dan kasus. Berbagai ranah pendekatan kualitatif juga memberikan kesempatan bagi ilmuan dibidang sosial untuk mengembangkan keilmuan sosiologi lebih otonom. ${ }^{5}$

Penelitian kualitatif menurut $\mathbf{J}$ Meleong, memberikan kesmepatan untuk memahami fenomena sosial secara kontekstual, sehingga peneliti dapat berkomunikasi secara intensif dengan fenomena yang diteliti ${ }^{6}$. Dalam proses pengumpulan data, peneliti menggunakan beberapa teknik, seperti: wawancara, interview, dokumentasi dan juga grup discussion. Pemilihan daerah penelitian dilakukan atas dasar pertimbangan bahwa daerah tersebut sangat cocok untuk dijadikan tempat penelitian, Hal ini sangat penting supaya penelitian ini bisa maksimal, selain karena pertimbangan kedekatan wilayah peneliti yang berdomisili di Ponorogo. penelitian ini dilaksanakan di Desa Dadapan, Kecamatan Balong, Kabupaten Ponorogo.

Peneliti menggunakan metode snow ball sampling dimana peneliti melakukan tes, terhadap 3 (tiga) orang responden, kemudian dari data tersebut digali kembali, informasi hingga kebutuhan data yang diperlukan berhasil dikumpulkan.Hal ini digunakan untuk mengetahui susunan dan pembatasan informan yang mungkin dipilih agar memenuhi kriteria dari data yang dibutuhkan. Menurut Usman dan Akbar mengatakan bahwa snowball sampling akan akan terus berkembang sampai dianggap data yang yang dikumpulkan representative ${ }^{7}$.

5 Somantri GR. Memahami metode kualitatif. Makara, Sos Hum. 2005;9(2):57-65. http://journal.ui.ac.id/index.php/humanities/article/view/122/118.

6 Herdiansyah, Haris. 2010. Metodologi Penelitian Kualitatif untuk Ilmu-Ilmu Sosial. Jakarta: Salemba Humanika. www.ejournal.-s1.undip.ac.id

7 Fallis A. No Title No Title. J Chem Inf Model. 2013;53(9):1689-1699. doi:10.1017/CBO9781107415324.004, etheses.uin-malang.ac.id 


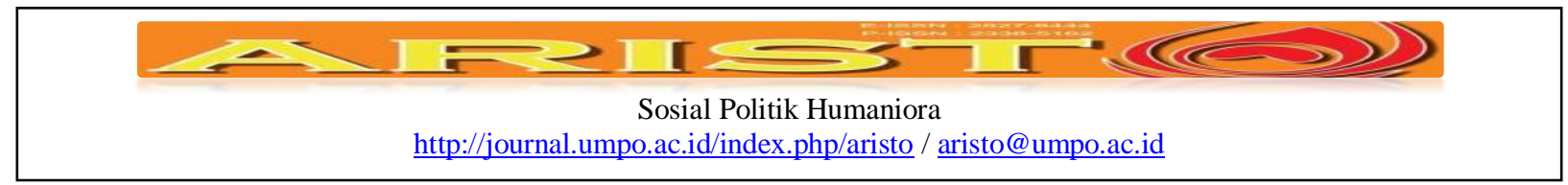

Menurut Lofland dalam Moleong menjelaskan bahwa dalam penelitian kualitatif katakata dan tindakan adalah sumber data utama, dokumen, laporan dan lain - lain merupakan data pendukung. Kita ketahui bahwa dalam penelitian kuantitatif terdapat subyek penelitian yang di jadikan sebagai sampling atau sampel, sednagkan dalam penelitian kualitatif lebih dikenal dnegan istilah informan atau pelaku, pendapat atau kata-kata, serta tindakan dari informan itulah yang kemudian menjadi sumber yang diamati atau di observasi dengan cara diskusi, wawancara dan dokumentasi. Pelaku tersebut atau orang yang digali informasinya disebut keyinformans atau yang dijadikan narasumber kunci terhadap persoalan yang akan diteliti. Data - data tersebut dikumpulkan melalui proses pengumpulan data dari seumber datu ke sumber yang lain dnegan cara menggelinding, hingga terpenuhi informasi atau data yang di butuhkan, inilah teknik yang dinamai sebagai snowball smapling ${ }^{8}$.

Miles dan Huberman menjelaskan tentang alur analisis data pada penelitian kualitatif dengan tiga tahapan besar, yakni: reduksi data, penyajian data, dan penarikan kesimpulan. Reduksi data sendiri adalah proses pemilihan data kemudian dilanjutkan dengan penyederhanaan serta pemilahan data hasil penelitian di lapangan dari catatan-catatan yang telah dibuat oleh peneliti. Prosesnya dilakukan secara detail dan di salin terus - menerus selama proses penelitian. Kemudian proses selanjutnya adalah Reduksi data, dengan cara: meresume, di kodifikasi, sehingga terlihat jelas data sesuai dengan kebutuhan data. Reduksi data nantinya akan menampilkan data yang diperlukan, sehingga data - data yang dianggap tidak perlu bisa dihilangkan ${ }^{9}$.

Penelitian kualitatif berbeda dengan penelitian kuantitatif, dimana peneliti merupakan pengumpul data atau bagian dari instrument penelitian, melalui observasi langsung dan wawancara sehingga tidak terkontrol keberadaannya, sehingga subyektivitas data perlu dilakukan pengujian keabsahan data. Moleong berpendapat bahwa ada beberapa criteria dalam pengujian

${ }^{8}$ Djaelani AR. Teknik Pengumpulan Data Dalam Penelitian Kualitatif. FPTK IKIP Veteran Semarang. 2013:82-92.

${ }^{9}$ Miles, MB dan AM Huberman. (1992). Qualitative Data Analysis: A Sourcebook of New Methods. SAGE. 


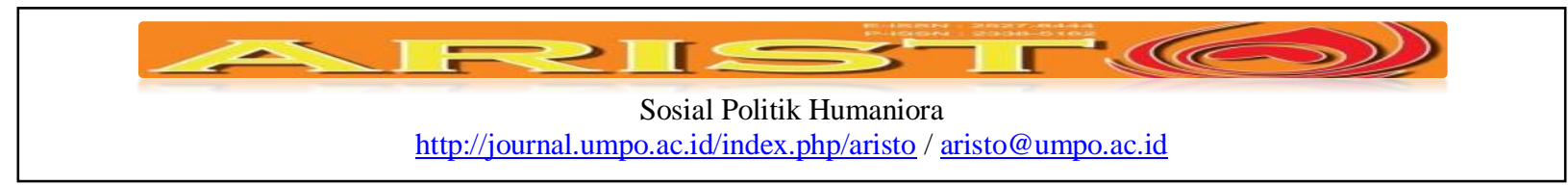

kebasahan data, diantaranya: (1) Credibility / derajat kepercayaan; (2) Transferability / keteralihan; (3) Dependability / kebergantungan dan; (4) Confirmability / kepastian. ${ }^{10}$

\section{Gambar 4.1 Skema Pengolahan dan analisis data}

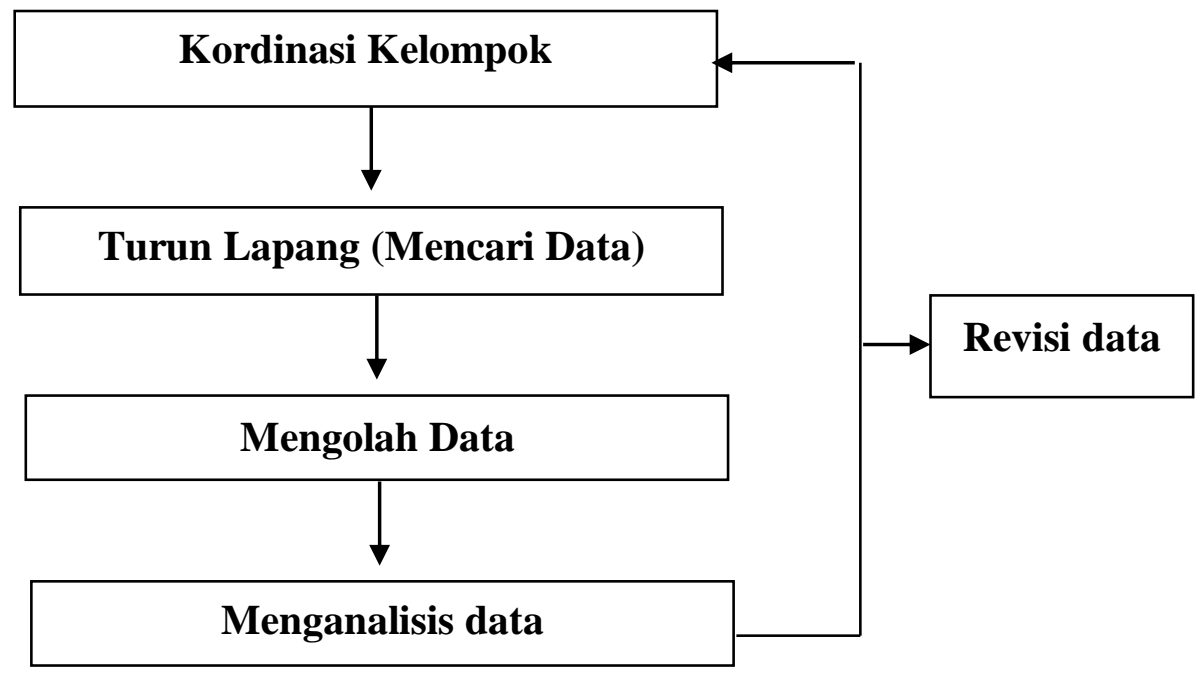

Beberapa kajian yang telah ada, tidak banyak kajian yang mengulas tentang model pemberdayaan berbasis komunitas, yang ada yakni model - model meanfaatan program pemberdayaan yang bersifat partisipatif, sehingga kajian yang membahas permasalahan program pemberdayaan berbasis komunitasmasih sedikit, dan fokusnya hanya pada peranan organisasi, bukan konsep pemberdayaan yang berangkat dari komunitas yang ada pada wilayah tersebut.untuk memperjelas kajian ini, maka kami akan melakukan Literatur Review untuk menegaskan bahwa kajian ini memang belum ada, sehingga menarik dan orisginalitasnya dapat dipertanggungjawabkan.

Pemberdayaan Masyarakat melalui Pendekatan Kelompok: Kasus Pemberdayaan Masyarakat Miskin melalui Pendekatan Kelompok Usaha Bersama (KUBE). Memiliki Ada 5 faktor utama eksistensi KUBE, yaitu: aset (asset), kemampuan(ability), kemasyarakatan (community), komitmen (commitment), pasar (market) selanjutnya diberi nama "KONSEP PEMBERDAYAAN ABCCM". Tiga faktor kedinamisan KUBE, yaitu: pendampingan (guide), jaringan kerjasama (networking), dan inovasi (innovation). Ada beberapa variabel yang saling mempengaruhi dalam model, yaitu variabel dinamika kehidupan KUBE dipengaruhi pola pemberdayaan, karakteristik individu KUBE, dan

\footnotetext{
${ }^{10}$ Ibid, S RWV.
} 


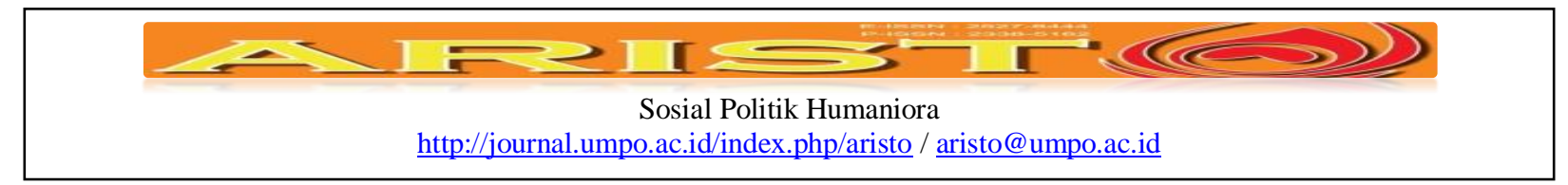

lingkungan sosial KUBE. Sedangkan variabel tingkat keberhasilan KUBE dipengaruhi oleh dinamika kehidupan KUBE. ${ }^{11}$

The complexity of the problem drive the worldwide commitment in reducing poverty all over the world by the draft of development goals, called Millennium Development Goals (MDGs)To promote the development, the effort to reduce poverty that mainly started by the unemployment must involve the society in participative platform. The participation pattern possibly reducing poverty to be more grounded, strengthencommitment between society in responsibility to reduce unwelfare. The local genius, for instance Lembaga Perkreditan Desa (LPD) that is own by the village association has the strategic role in reducing poverty trough the improvementof its social function beside the main function which is to improve the members welfare. The social function means the commitment and togetherness between member to institution and between members. ${ }^{12}$

Kedi Suradisastra, STRATEGI PEMBERDAYAAN KELEMBAGAAN PETANI Farmer's Institutional Empowerment Strategy, PusatProses pengambilan keputusan dalam masyarakat petani merupakan suatu tindakan berbasis kondisi komunitas (communitybased action) yang dapat dimanfaatkan sebagai salah satu celah masuk (entry-point) upaya diseminasi teknologi. Dengan demikian setiap upaya pemberdayaan kelembagaan petani memiliki keterkaitan kuat dengan kondisi tekno-sosial komunitas petani.Keberhasilan suatu program pemberdayaan merupakan resultan interaksi elemenelemen pemberdayaan dengan strategi pemberdayaan yang diterapkan.Upaya dan strategi pemberdayaan merupakan suatu pendulum antara paradigma evolusi dan paradigma revolusi yang saling mengisi (overlap) dalam proporsi yang sesuai dengan kondisi dan kebutuhan kelembagaan petani ${ }^{13}$.

Para janda didapatkan bertahan hidup untuk memperjuangkan keterbatasan ekonomi rumah tangga mereka.Tujuan dari penelitian ini adalah untuk mengetahui peran janda dengan tingkat pendapatan rendah yang bertanggung jawab untuk membiayai rumah tangga mereka. Selain itu, penelitian ini memiliki tujuan untuk merumuskan strategi pemberdayaan mereka. Penelitian ini menemukan bahwa tingkat pemberdayaan dalam akses ekonomi, politik, dan sosial bagi para janda masih jauh dari kondisi sempurna. Penelitian ini menguraikan strategi untuk memberdayakan para janda melalui peningkatan produktivitas para responden, perluasan akses pendidikan, menyediakan pelatihan untuk meningkatkan keterampilan dan manajemen advokasi keluarga ${ }^{14}$

\footnotetext{
${ }^{11}$ Tampubolon J. Pemberdayaan masyarakat melalui pendekatan kelompok. skripsi. 2006.

${ }^{12}$ I G. W. Murjana Yasa. 2005:86-91

13 Suradisastra K. Farmer’ s Institutional Empowerment Strategy. 2008;26(70):82-91.
}

${ }^{14}$ S RWV, Ekonomika F, Bisnis dan, Diponegoro U. Analisis peran ganda dan strategi pemberdayaan janda yang bekerja di kota semarang. 2013. 


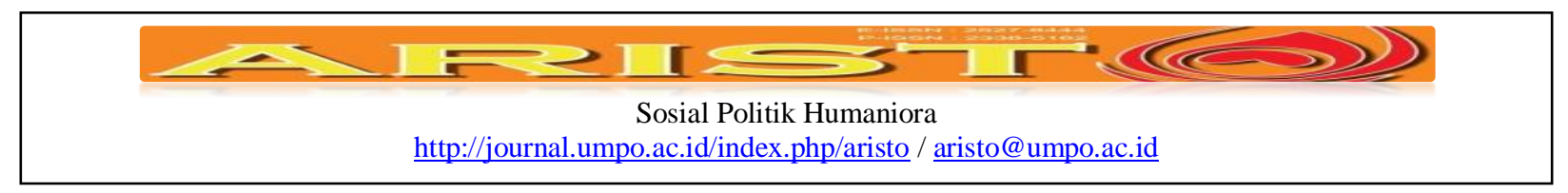

Menurut Santrock Kehilangan pasangan hidup akibat kematian pasangan membuat individu memiliki satatus sebagai janda ataupun duda. Pada seorang perempuan, menyandang status sebagai janda tidaklah mudah, karena semua pasangan hidup khususnya perempuan berharap pernikahan yang dibangun, bisa bertahan hingga ajal menjemput, sehingga usia pasangan bisa mencapai kakek dan nenek, dengan menjalankan tugas serta tanggungjawabnya. ${ }^{15}$

The stigma attached to these women implies that they are unmarriageable, whether because of their looks, their behaviour or the status of their family. Parents and extended family exert remorseless pressure on women who are still unmarried in their midtwenties to find a man; they often threaten to, and not uncommonly do, arrange their daughter's marriage, with or without the consent of their daughter. Unmarried women in their thirties often suffer social exclusion and relegation to child status, e.g. in life-cycle ceremonies and representation in local gov-ernment. Single women who have become pregnant are also stigmatised, to the extent that it is extremely rare to find an unmarried mother in Indonesia, If still at school, they are usually forced to leave school. As Situmorang said, 'childbearing out of wedlock is unacceptable. ${ }^{16}$

Kegagalan pembangunan yang di gagas selama ini, disebabkan karena terlalu terfokus pada konsep ekonomis, selain itu pembangunan yang dilakukan tidak bersifat partisipatif, sehingga ada kesan jika masyarakat hanya dijadikan obyek, sehingga dikemudian hari kemudian menimbulkan problem baru berupa kesenjangan, dan berbagai macam bentuk ketergantungan yang berbahaya.

Paradigma yang berkembang di dunia mengenai program pemberdayaan memiliki dua kubu besar, yaitu: Pertama, asumsi yang berkembang di antara para aktivis sosial pada tahun 1970an yang di ilhami oleh semangat developmentalisme. Pondasi dari kubu ini, menitikberatkan pada kesadaran naif atau refomatif, yang hanya melihat faktor manusia sebagai akar masalah ketidakberdayaan dalam kehidupan. Kubu ini, secara umum hanya menolak konsep pendekatan pembangunan, yang selama ini dianggap sebagai biang keladi, yaitu pendekatan 'bottom up' melawan pendekatan 'top down'. sehingga disimpulkan bahwa diperlukan sebuah metode yang sesuai agar program - progam pemerintah, bisa berjalan dan mencapai tujuan. kemudian bottom up serta partisipasi masyarakat menjadi isu - siu strategis dalam pelaksanaan pembangunan. Mereka mengutarakan bahwa kegagalan yang selama ini dialami lebih pada

\footnotetext{
${ }^{15}$ Setyowati L, Psikologi F, Surakarta UM. Kebermaknaan hidup pada janda. 2014.

${ }^{16}$ Parker, Lyn. Ibid
}

Yusuf Adam Hilman, Elok Putri Nimasari. Model Program Pemberdayaan Masyarakat Desa Berbasis Komunitas./ 04/ Vol. 6. No. 1. Tahun 2018 


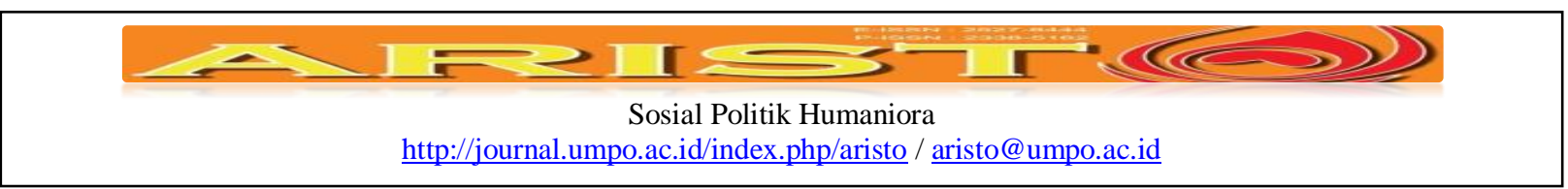

model pendekatan konvensional yang diantaranya adalah transplantative planning, top down, inductive, capital intensive, west-biased technological transfer, dan sejenisnya. Sehingga dianggap kurang tepat, alhasil pembangunan yang ada di Negara - Negara tersebut, hanya menghasilkan, beberapa hal, diantaranya: 1). Pembangunan tidak menghasilkan kemajuan, melainkan justru semakin meningkatkan keterbelakangan (the development of underdevelopment), 2).Melahirkan ketergantungan (dependency) negara sedang berkembang terhadap negara maju. 3). Melahirkan ketergantungan (dependency) pheriphery terhadap center. 4). Melahirkan ketergantungan (dependency) masyarakat terhadap Negara / pemerintah. 5). Melahirkan ketergantungan (dependency) masyarakat kecil (buruh, usaha kecil, tani, nelayan, dll.) terhadap pemilik modal. ${ }^{17}$

Kondisi tersebut jika diteruskan maka akan membahayakan, karena sekali lagi korbanya adalah masyarakat lemah yang tidak berdaya, salah satu penyelesaian yang logis dan mungkin dilakukan yakni merubah konsep atau paradigma dengan lebih menekankan pada kegiatan yang bersifat partisipatif, dengan menjadikan masyarakat sebagai subyek dengan cara memberikan kesempatan untuk merubah nasib dan keadaan agar lebih sejahtera lagi.

Pemberdayaan masyaakat sejatinya adalah proses dimana masyarakat diberikan kesempatan untuk meningkatkan harkat dan martabatnya, sehingga masyarakat menjadi komunitas yang memiliki ketahanan dalam berbagai sektor dalam lini kehidupan. Ada dua sudut pandnag yang berkembang terkait aktifitas pemberdayaan masyarakat, yakni: Pertama, menempatkan masyarakat untuk memiliki posisi yang kuat dalam kehidupan sehari - hari. Posisi tersebut bukan sebagai penerima manfaat (beneficiaries) yang dapat menjadikan amsyarakat menjadi ketergantungan, posisi yangs eharusnya adalah subyek (agen atau partisipan yang bertindak) yang bergerak secara kolektif untuk mencapai kemandirian. Namun demikian, menjadi mandiri tidak lantas Negara lepas tangan, tetapi masih diperlukan terutama dalam beberapa bidang, yang menjadi tanggungjawab Negara, seperti pemberian layanan publik (kesehatan, pendidikan, perumahan, transportasi dan seterusnya) kepada masyarakat tentu merupakan tugas (kewajiban) negara. Masyarakat yang mandiri sebagai partisipan berarti terbukanya ruang dan kapasitas mengembangkan potensi-kreasi, mengontrol lingkungan dan sumberdayanya sendiri, menyelesaikan masalah secara mandiri, dan ikut menentukan proses

${ }^{17}$ Widayanti, S. (2012). Pemberdayaan Masyarakat : Pendekatan Teoritis. Welfare Ilmu Kesejahteraan Sosial , 87-102

Yusuf Adam Hilman, Elok Putri Nimasari. Model Program Pemberdayaan Masyarakat Desa Berbasis Komunitas./ 04/ Vol. 6. No. 1. Tahun 2018 


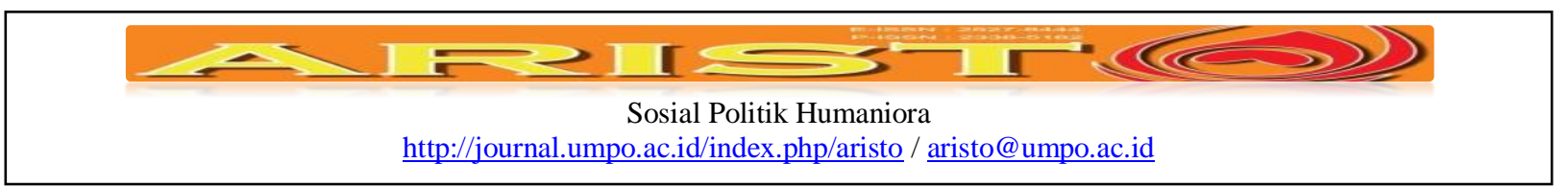

politik di ranah negara. Masyarakat ikut berpartisipasi dalam proses pembangunan dan pemerintahan $^{18}$

Pemberdayaan masyarakat merupakan proses depowerment penyebarluasan dari sistem kekuasaan Negara yang bersifat mutlak-absolut (intelektual, religious, politik, ekonomi, dan militer). Dalam penjelasan Talcot Parson, kekuasaan dalam masyarakat adalah variabel jumlah. Jumlah disini adalah power atau kekuasaan dari masyarakat yang berupa kekuatan anggota masyarakat secara menyeluruh yang kemudian disebut sebagai tujuan kolektif (misalnya, dalam pembangunan ekonomi). Konsep pemberdayaan dihubungkan dengan konsep mandiri, partisipasi, jaringan kerja, dan keadilan. Pada dasarnya, pemberdayaan diletakkan pada kekuatan tingkat individu dan sosial. Orang-orang yang telah mencapai tujuan kolektif diberdayakan melalui kemandiriannya, bahkan merupakan"keharusan" untuk lebih diberdayakan melalui usaha mereka sendiri dan akumulasi pengetahuan, keterampilan serta sumber lainnya dalam rangka mencapai tujuan mereka tanpa bergantung pada pertolongan dari hubungan eksternal (ElMandary, n.d.) ${ }^{19}$

Menurut Jim Ife pemberdayan adalah: "empowerment means providing people with the resources, oppurtunities, knowledge, and skills to increase their capacity to determine their own future, and to participate in and affect the life of their community". Sedangkan Suhendra berpendapat bahwa pemberdayan masyarakat adalah penyebarluasan kekuasaan kepada masyarakat agar mereka mampu menjadi komunitas atau individu yang mandiri. ${ }^{20}$

Perspektif yang berkembang selama ini adalah masyarakat yang dijadikan sebagai subyek bukan sebagai obyek, sehingga masyarakat mengalami ketergantungan, sehingga programprogram pemberdayaan sulit mencapai tujuan, jika kemudian masyarakat diletakan sebagai obyek, akan lebih mudah dalam mencapai tujuannya, disinlah perlu diciptakan suasana atau iklim yang memungkinkan potensi masyarakat bisa dikembangkan. Kearifan lokal merupakan salah satu kunci tentang bagaimana masyarakat dapat memahami dirinya sendiri, termasuk

18 Cholisin. (2011, Desember). Pemberdayaan Masyarakat. Disampaikan Pada Gladi Manajemen Pemerintahan Desa Bagi Kepala Bagian/Kepala Urusan Hasil Pengisian Tahun 2011 Di Lingkungan Kabupaten Sleman, 19-20 Desember 2011, Pp. 19-20.

${ }^{19}$ Diah, A. (2015). Pembangunan Kemandirian Desa Melalui Konsep Pemberdayaan: Suatu Kajian Dalam Perspektif Sosiologi. Sosio Informa, 175-188

${ }^{20}$ Hidayat, T. (2010, September). Isu-Isu Aktual Penelitian Pemberdayaan Masyarakat. Pp. 1 - 11

Yusuf Adam Hilman, Elok Putri Nimasari. Model Program Pemberdayaan Masyarakat Desa Berbasis Komunitas./ 04/ Vol. 6. No. 1. Tahun 2018 


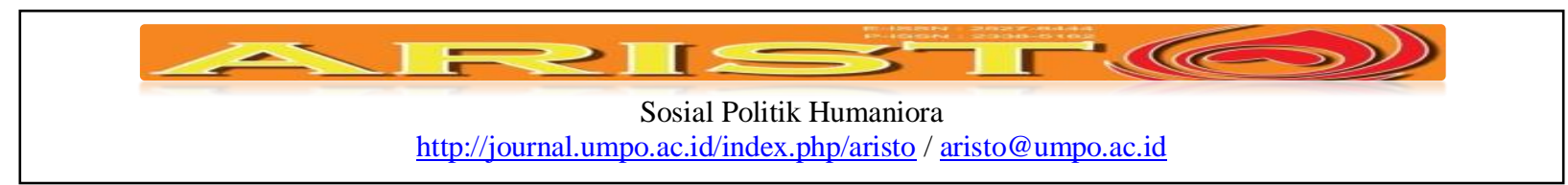

ekmampuan masyarakat untuk menyesuaikan dengan kondisi masyarakat. tindakan konkrit yang bisa dilakukan yakni, penyediaan berbagai input serta memberikan akses pendukung potensi yang bisa membuat masyarakat menjadi makin berdaya, yakni dengan memberikan kepercayaan (trust) kepada mereka dalam mengelola input dan peluang tersebut. ${ }^{21}$

Ledwith berpendapat bahwa, ada 4 (empat) dimensi dasar dalam sebuah aktifitas pemberdayaan suatu komunitas, yakni: (i) pemberdayaan personal melalui pembelajaran, pengetahuan, kepercayaan diri, dan skill; (ii) aksi positif yang terkait dengan kemiskinan, kesehatan, ras, gender, ketidakmampuan/cacat, serta aspek- aspek diskriminasi yang menentang struktur kekuasaan; (iii) organisasi komunitas yang menyangkut kualitas dan keefektifan kelompok komunitas serta hubungan masing-masing kelompok dan dengan pihak luar; (iv) partisipasi dan keterlibatan untuk menuju perubahan komunitas ke arah yang lebih baik. ${ }^{22}$

Konsep pemberdayaan masyarakat sebagai sebuah kritik terhadap konsep pembangunan yang dikatan sebagai developmentalisme yang tidak kunjung menciptakan kesejahteraan, karena malah menjadi sebab tumbuhnya ketergantungan dan kesenjangan sosial, kemudian mulai tereduksi terhadap program - program di kehidupan masyarakat yang menekankan pada partisipasi yang benar - benar menjadikan manusia sebagai subyek bukan lagi obyek, sehingga setiap pribadi memiliki kesempatan untuk menentukan nasib dan juga kesejahteraannya masing - masing tentunya secara kolektif. Model dan juga skema konsep pemberdayaan, bisa di ilustrasikan sebagai berikut.

\section{Gambar 2.1 Kerangka teoritis Pemberdayaan Masyarakat}

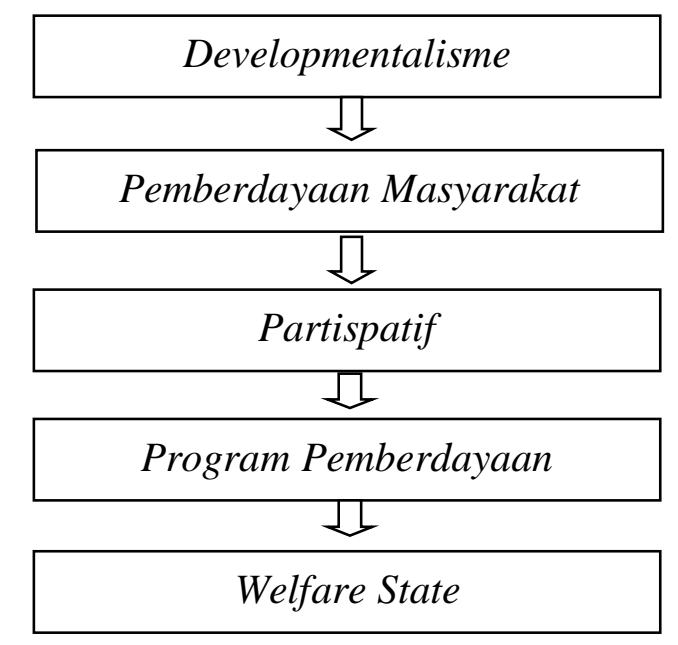

\footnotetext{
${ }^{21}$ Ibid

${ }^{22}$ Opcit
} 


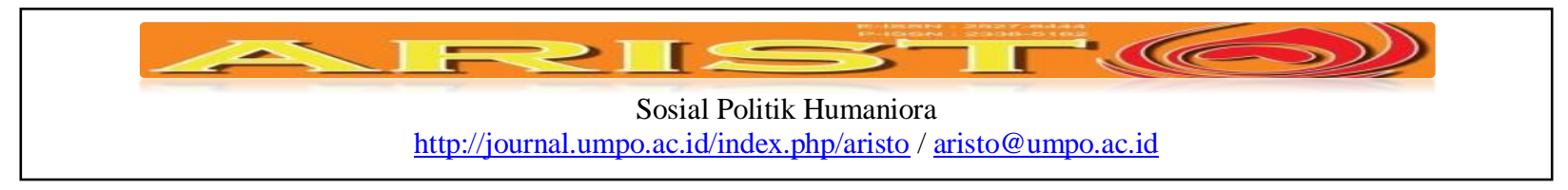

Pemberdayaan masyarakat merupakan bagian dari paradigma pembangunan yang lebih menitikberatkan pada seluruh aspek utama dari manusia dan lingkungannya, mulai dari aspek intelektual (Sumber Daya Manusia), aspek material dan fisik, sampai kepada aspek manajerial. Aspek-aspek tersebut bisa dapat dikembangkan menjadi aspek sosial, budaya, ekonomi, politik, keamanan dan lingkungan. ${ }^{23}$

Secara harfiah pemberdayaan menurut Sharp diartikan memberikan daya atau kekuatan kepada seorang individu dalam hal ini komunitas masyarakat, selain itu juga pemberdayaan bisa dilaksanakan dengan 2 (dua) cara, yakni: secara konseptual dan empirik. Secara konseptual lebih menekankan pada aspek 'pendidikan kesadaran' (consciousness education) sebagaimana yang diterapkan, dikembangkan dan disebarluaskan oleh Freire pada tahun 1970-an (seorang pendidik dari Brasil). pemberdayaan dijadikan sebagai sebuah sarana positif, yang lebih memungkinkan masyarakat dapat melakukan hal-hal tersebut, tanpa menunggu aksi dari faktor diluar mereka. Sedangkan empirik, yaitu berbagai bentuk program latihan yang bersifat partisipatif, sehingga dapat membuka pikiran masyarakat desa tentang bagaimana mereka dapat memperbaiki kehidupan mereka dengan cara yang praktis (by doing), dan menolong orang yang kurang berdaya dalam lingkungannya. Cara ini lebih menyadarkan mereka terhadap permasalahan kemiskinan yang ada dalam komunitasnya dan membantu mereka memahami sistem yang telah ada yang telah membatasi dan menghimpit mereka. Kesadaran ini akan mendorong mereka melakukan berbagai aksi untuk ke luar dari sistem kemiskinan. ${ }^{24}$

Ada 3 (tiga) pendekatan yang bisa digunakan dalam menjalankan program pemberdayaan, yaitu; 1). Pendekatan mikro, secara praktis caranya bisa melalui bimbingan, konseling, stress managemet, intervensi krisis. Tujuan utamanya adalah membimbing atau melatih individu dalam menjalankan tugas-tugas dalam kehidupannya. Model ini sering disebut pendekatan yang berpusat pada tugas (task centered approach). 2). Pendekatan mezzo yaitu memanfaatkan keberadaan kelompok sebagai media intervensi atau treatment. Caranya yakni melalui, Pendidikan dan pelatihan, dinamika kelompok, biasanya digunakan sebagai strategi dalam meningkatkan kesadaran, pengetahuan, keterampilan, dan sikap individu agar memiliki kemampuan memecahkan permasalahan yang dihadapinya. 3). Pendekatan makro atau yang

\footnotetext{
${ }^{23}$ Desa PM. wong cilik". 2006;(2000):1-21.

${ }^{24}$ Ibid Tampubolon J.
} 


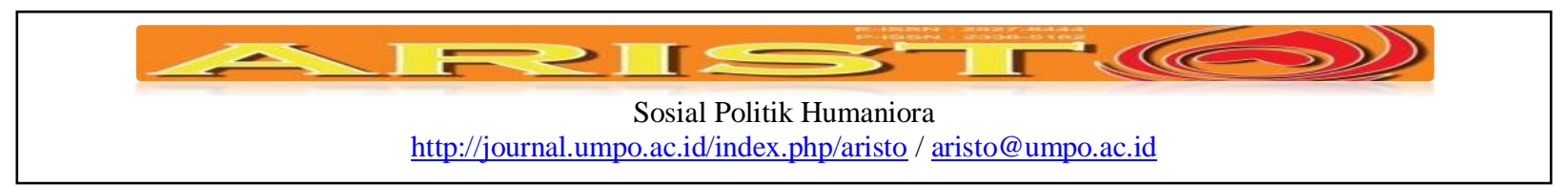

biasanya disebut strategi sistem besar (large-system strategy), karena sasaran perubahan diarahkan pada sistem lingkungan yang lebih luas seperti perumusan kebijakan, perencanaan sosial, kampanye, aksi sosial, lobi, pengorganisasian dan pengembangan masyarakat, merupakan beberapa strategi dalam pendekatan ini.

\section{Hasil dan Pembahasan}

Desa Dadapan Kecamatan Balong, merupakan salah satu daerah yang Kabupaten Ponorogo daerah ini beberapa waktu yang lalu menjadi sorotan media karena di gegerkan dengan penamaan "Kampung Janda”, namun beberapa pihak menjelaskan bahwa stigma tersebut tidak benar, sehinga menimbulkan kontroversi. Ada beberapa asumsi terkait keberadaan "janda" di desa itu. Mengishkan bahwa di desa ini dahulu terkenal dengan mitologi "mbok rondo" yang kemudian oleh masyarakat dipercaya kebenaranya, sehingga apabila ada perkawinan disitu, mitos nya tidak akan berlangsung lama atau awet, sehingga akan menyebabkan perceraian, hingga saat ini penduduk di daerah sekitar masih percaya. ${ }^{25}$

Desa Dadapan merupakan salah satu wilayah yang ada di Kabupaten Ponorogo dengan Kecamatannya Balong, mayoritas mata pencahariannya adalah petani, selain itu di daerah ini angka perceraiannya tinggi, banyak faktor yang menyebabkan hal mudal dari : 1). Pernikahan usia muda, 2). Faktor ekonomi, 3). Perselingkuhan, hingga 4). Faktor mitologi "Mbok Rondo". Terkait mitologi tersebut memang sejak saya kecil dulu sudah beredar cerita rakyat yang menjelaskan bahwa di desa kami memang ada kepercayaan jika usia pernikahan warga di daerah kami jarang sekali bisa langgeng atau awet tahan lama. Saya sendiri sebenarnya lebih cenderung pada alasan nomer satu dan dua, karena disini pernikahan dini dan faktor ekonomi sangat dominan menurut catatan yang ada di kantor desa kami. Jadi secara umum begitu kondisi desa kami. (Hasil Wawancara dengan Ibu Rusmiatin Lurah Dadapan)

Luas wilayah Desa Ddapan Kecamatan Balong Kabupaten Ponorogo sekitar \pm 192,46 Ha,

Dengan bata wilayah sebagai berikut:

Sebelah Utara

Sebelah Timur

Sebelah Selatan

Sebelah Selatan
: Desa Sedrajat

: Desa Jalen dan Desa Singkil

: Desa Gombang

: Desa Ngumpul dan Desa Bulu Kidul.

${ }^{25}$ Diakses dari http://www.sindopos.com/2016/02/profil-desa-kelurahan-desa-dadapan.html pada Juli 2017 


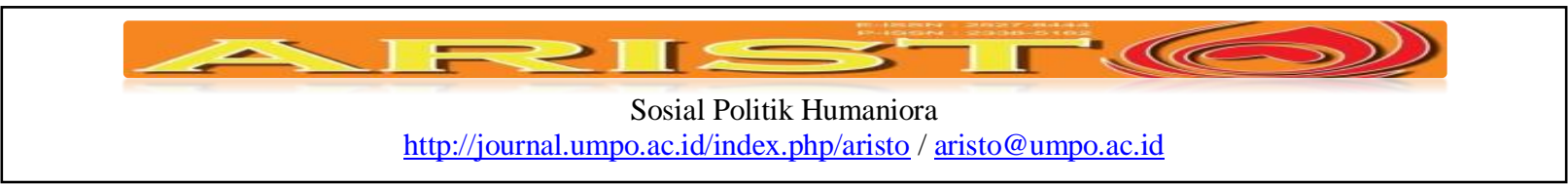

Gambar 5.1 Pencitraan Google Maps Desa Dadapan Kecamatan Balong Kabupaten Ponorogo

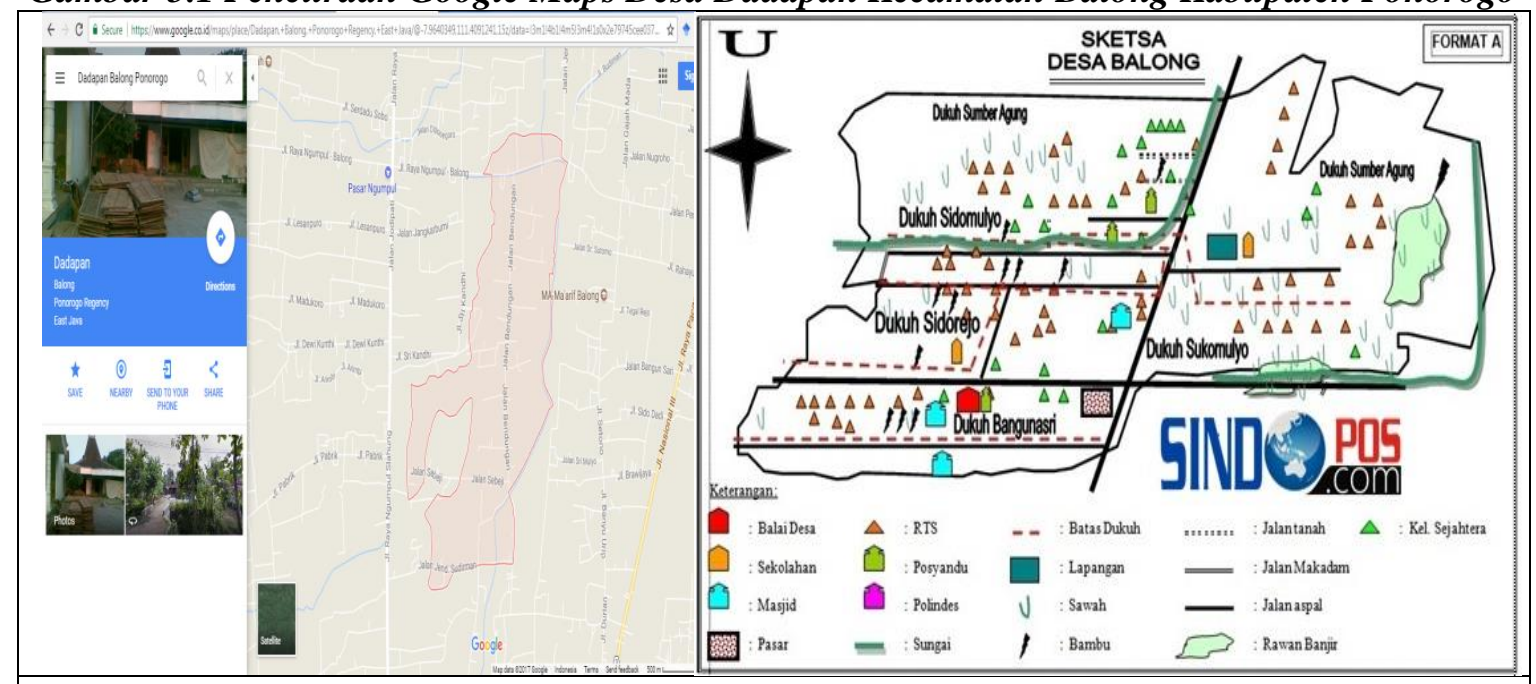

Sumber : Diolah dari Google Maps dan http://www.sindopos.com/2016/02/profil-desa-

kelurahan-desa-dadapan.html

Program pemberdayaan masyarakat yang dilakukan di “Kampung Janda”, Desa Dadapan

Kecamatan Balong, Kabupaten Ponorogo, secara umum programnya diperuntukan untuk ibu ibu yang berstatus “janda”, diantaranya: 1) Pembuatan Lumbung Dapur, 2). Pembuatan berbagai makanan olahan dari berbagai hasil pertanian, 3). Pelatihan kesenian. Hal ini di jelaskan dalam beberapa hasil wawancara.

Program - program yang ada di di desa diantaranya: pemberdayaan kelompok tani, paguyuban kesenian, dan juga kegiatan ibu - ibu. Kegiatanya sendiri bervariasi, mulai dari: pelatihan pertanian, kegiatan arisan, kegiatan berkesenian, dan berbagai aktifitas sosial lainnya. Sebenarnya program pemberdayaan nya sendiri secara umum sama dengan desa - desa lain yang ada di kabupaten Ponorogo, namun yang membedakan, kami coba melakukan kegiatan pemberdayaan secara kelompok, baik dilakukan oleh bapak - bapak maupun ibu - ibu. Bapak - bapak sendiri melakukan kegiatannya berkutat pada pengolahan hasil pertanian, dengan melakukan pelatihan dan juga musayawarah terkait bagaimana teknis bertani yang baik, penyusulahan tentang bibit pertanian, dan obat - obatan pertanian. Sedangkan ibu - ibu nya yang sebagian berstatus "janda" melakukan kegiatan pembuatan lumbung pangan melalui pemanfaatan wilayah sekitar pekarangan utuk ditanami sayur - sayuran yang nantinya bisa dimanfaatkan untuk menjadi lauk dan juga selebihnya bisa di jual kepasar sehingga bisa memberikan nilai ekonomis, selain itu ibu - ibu juga melakukan kegiatan diservifikasi pangan dnegan cara mengolah hasil pertanian untuk dikembangkan menjadi panganan atau jajanan yang bisa dikonsumsi sendiri untuk pemenuhan gizi dan juga dapat dijual untuk mennmbah nilai ekonomis, selagi menunggu hasil panen. (Hasil Wawancara dengan Ibu Rusmiatin Lurah Dadapan) 


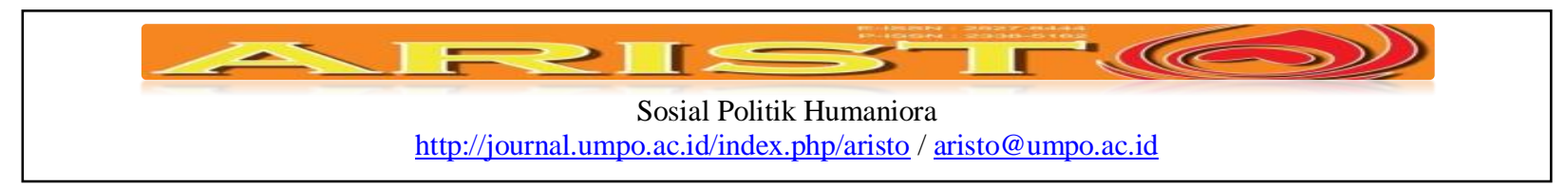

Sebenarnya banyak kegiatan pemberdayaan yang berbasis atau berangkat dari komunitas atau kelompok disini, diantaranta Melalui Kelompok Tani, Melalui Karang Taruna, Kelompok Kesenian Reog, Karawitan, kelompok yasinan Ibu/ Bapak, namun khusus untuk ibu, ibu kami ada tiga program yang dilakukan, yaitu: 1). Program pemanfaatan lahan sekitar untuk digunakan sebagai lumbung dapur, dimana ibu - ibu menanam sayur mayor di pekarangan yang di manajemen bersama dan kemudian hasilnya dimanfaatkan untuk kepentingan anggota dan juga untuk di jual ke pasar. 2). Program kegiatan pengolahan makanan dari hasil pertanian, yang menghasilkan berbagai jajanan yang bisa bernilai ekonomis. 3). Kegiatan kesenian, yang melibatkan ibu - ibu, disini ibu diberikan kesempatan utnuk berkreasi dalam bidang kesenian, sehingga kebutuhan ibu - ibu secara psikologis bisa terpenuhi. (Hasil Wawancara dengan Ibu Yati Ketua Kelompok Pemberdayaan Perempuan)

Kegiatannya secara umum yakni pelatihan menanam sayuran di pekarangan, kemudian melakukan kegiatan pelatihan pembuatan jajanan dari olahan hasil pertanian, hingga berlatih kesenian, programnya dilakukan secara priodik dan terus - menerus. Pokoknya kalo bagi saya sangat membantu, karena selama ini kami tidak bisa memanfaatkan potensi yang dimiliki, dengan adanya pelatihan ini kami menjadi memiliki pengetahuan dan juga ketrampilan yang bisa diterapkan dalam kehidupan masyarakat. (Hasil Wawancara dengan Ibu Sumi Anggota Kelompok Pemberdayaan Perempuan)

Kegiatan pemberdayaan masyarakat yang dilakukan oleh ibu - ibu meliputi: 1). Pembuatan lumbung dapur dengan menanam sayuran sehari - hari bagi masyarakat yang ditanam di pekarangan rumah, 2). Pembuatan beberapa olahanan makanan dari hasil pertanian, singkong, talas, dan dilakukan pengemasan, 3). Melakukan pelatihan kesenian melalui kelompok kesenian reog dan karawitan. (Hasil Wawancara dengan Ibu Harmi Anggota Kelompok Pemberdayaan Perempuan)

3 (tiga) Jenis kegiatan dalam Program Pemberdayaan Masyarakat yang dilakukan oleh ibu - ibu yang notabenne - nya berstatus “Janda”, dipilih karena sesuai dengan kondisi mereka, yang secara umum memiliki sumber penghidupan di bidang pertanian (agraris), selain itu di Desa Dadapan juga memiliki kesenian yang perlu di hidupkan karena sudah lama fakum, hal ini sangat tepat. 


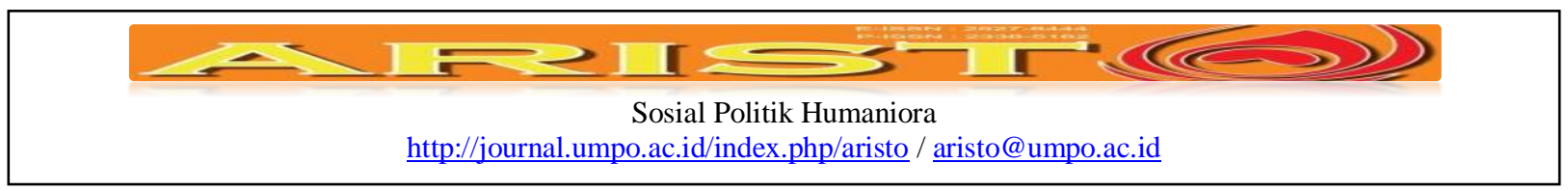

Gambar 5.2 Proses awal hingga akhir program pembuatan jajanan atau makanan kecil dari hasil pertanian masyarakat

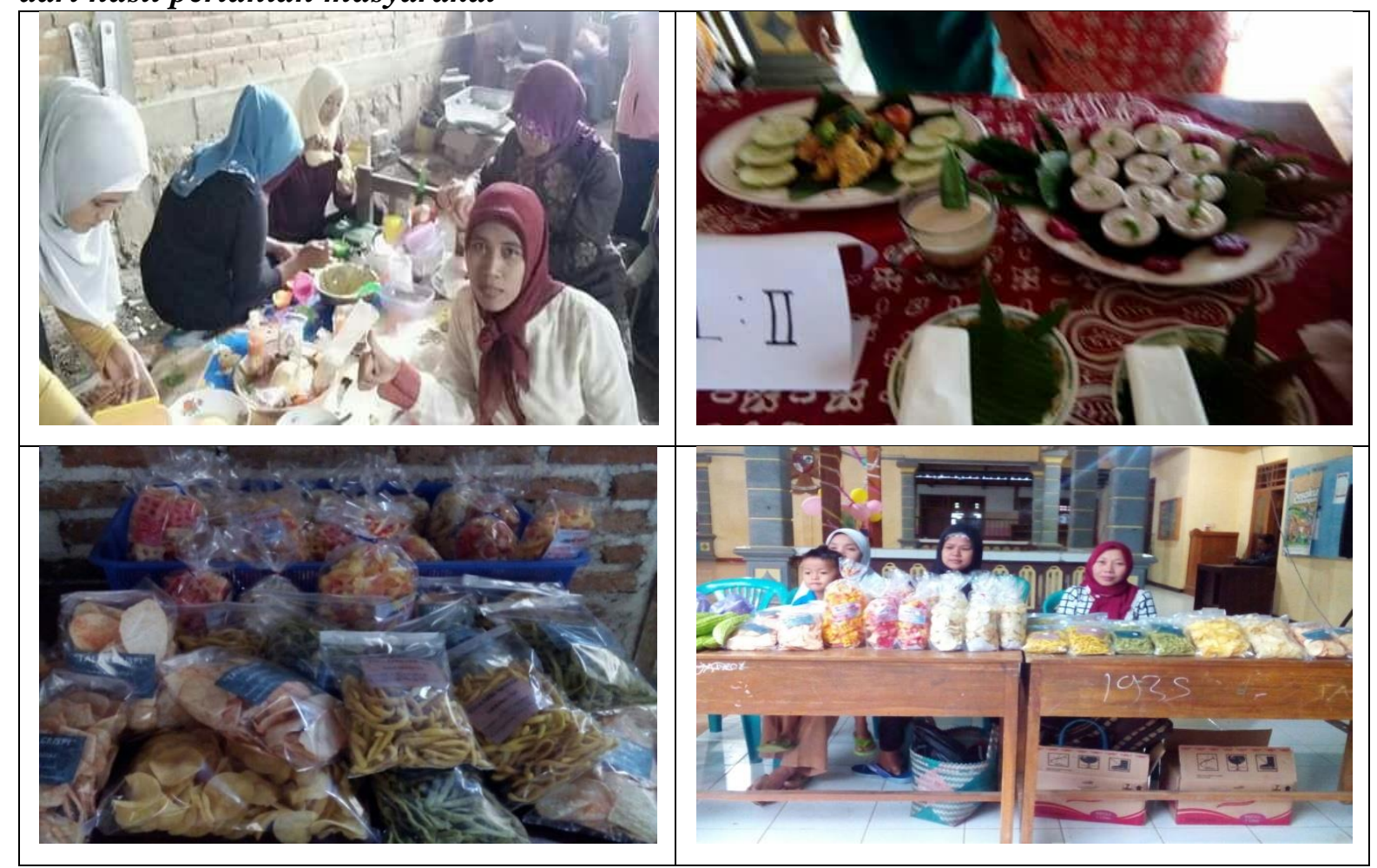

Sumber: Dokumentasi peneliti

Para warga masyarakat sedang melakukan kegiatan pengolahan jajanan dan makanan ringan berbahan dasar hasil pertanian penduduk setempat, disinilah masyarakat dilatih ketrampilan membuat jajanan dan makanan kecil. Proses nya sangat sederhana, bahannya juga bisa diperoleh dari kebun sendiri dan hasilnya bisa di jual untuk menambah pemasukan dan lain sebagainya, tentunya sangat bermanfaat sekali. 


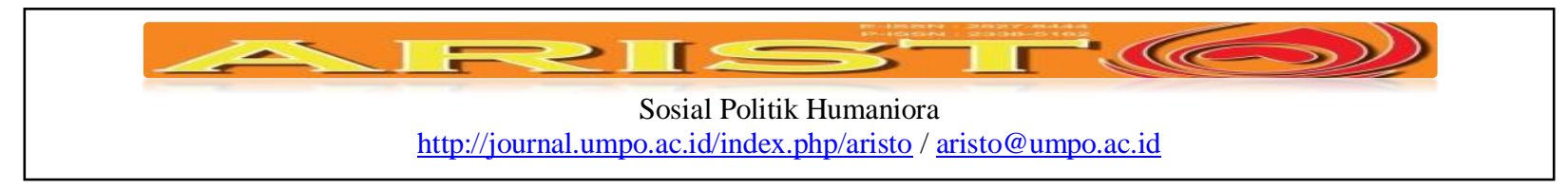

Gambar 5.3 Proses awal hingga akhir program pelatihan kesenian

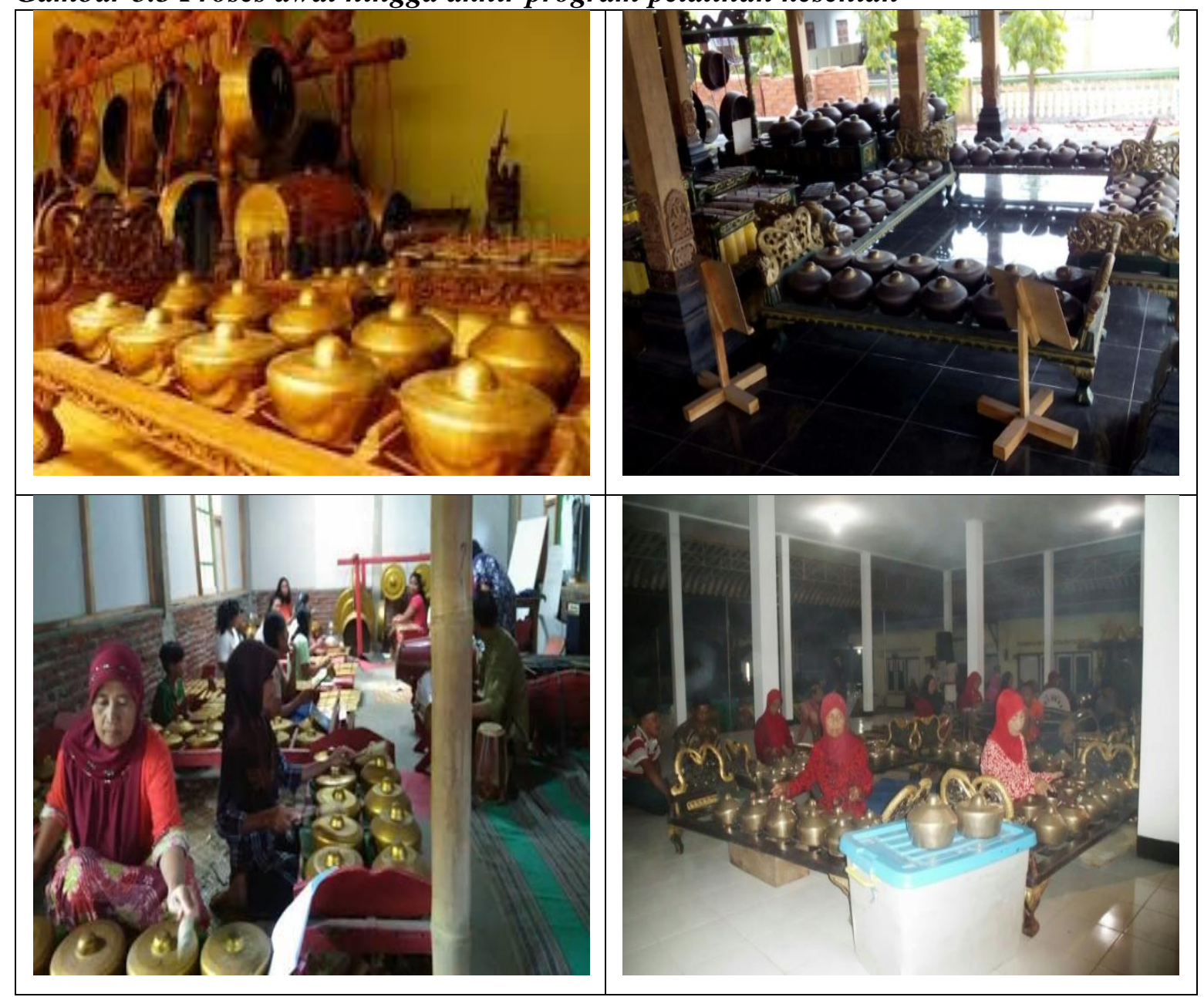

\section{Sumber: Dokumentasi peneliti}

Ibu - ibu sedang melakukan kegiatan berlatih ketrampilan karawitan, untuk menghidupkan kembali kesenian Desa Dadapan, selain itu dengan berlatih seni, ibu - ibu dituntut untuk tampil percaya diri dan juga bangga akan kehidupannya. 


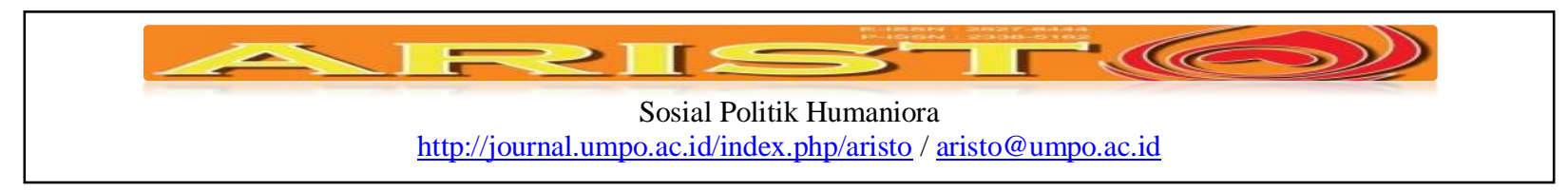

Gambar 5.4 Proses Kegiatan Pemberdayaan lumbung Dapur

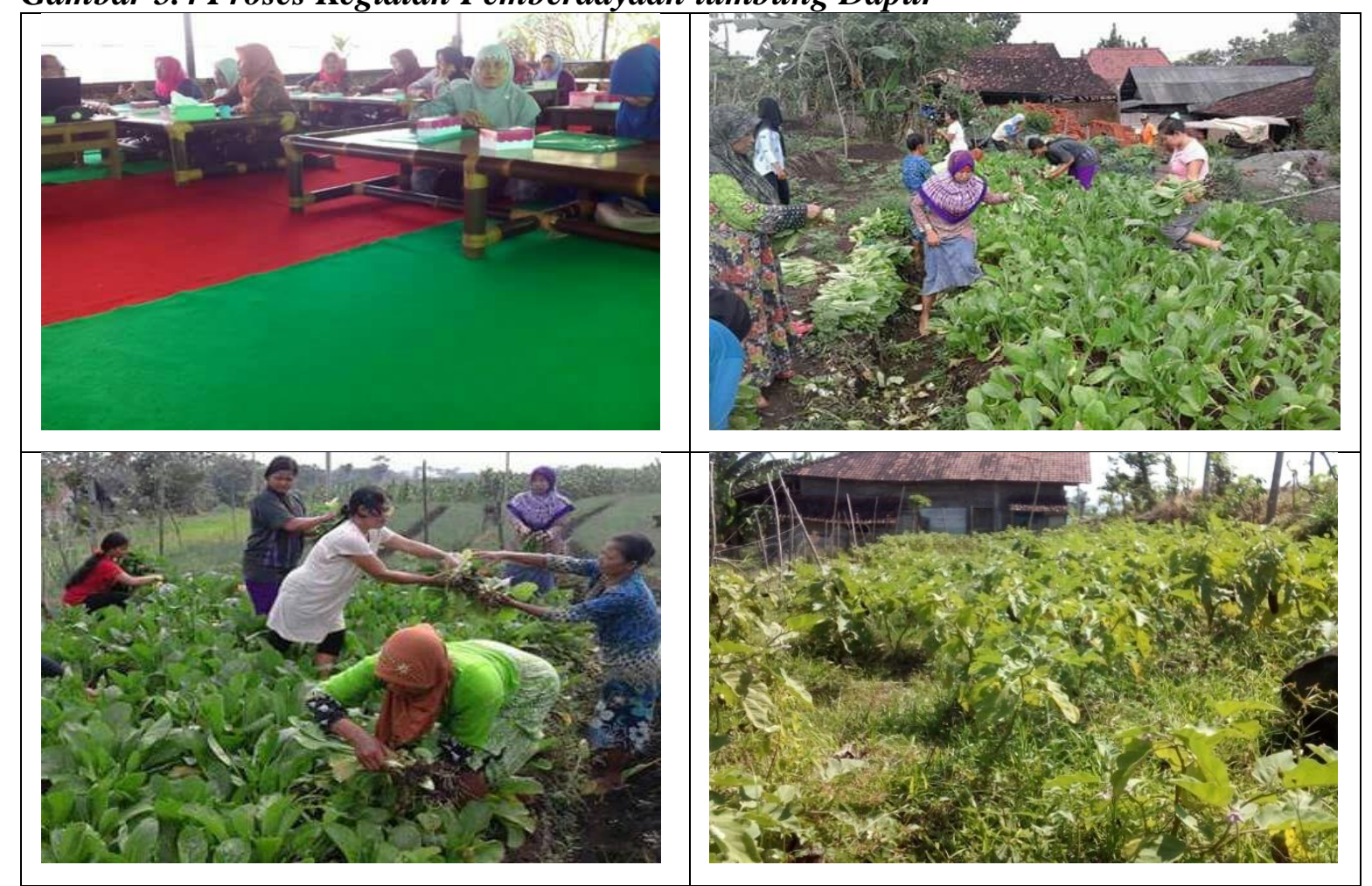

\section{Sumber: Dokumentasi peneliti}

Ibu - ibu ini sedang melaksanakan program lumbung dapur guna memenuhi kebutuhan dapur sehari - hari selain itu dengan adanya program ini, masyarakat juga bisa menjual hasil panenenya untuk menambah penghasilan keluarga.

Program - program pemberdayaan masyarakat yang dilakukan oleh ibu - ibu yang menyandang status "Janda", dengan berbagai bentuk, telah banyak membawa perubahan bagi masyarakat, hal tersebut tidak terlepas dari apa yang selama ini anggota masyarakat rasakan, yakni: persoalan ekonomi, persoalan kelektifitas, dan juga persoalan budaya.

Masyarakat bisa memiliki kegiatan tambahan untuk mengisi waktu luang, dalam kegiatan tersebut masyarakat merasakan dampak ekonomis, sosial dan juga kepercayaan diri, yang tumbuh karena adanya kemandirian dan juga semanggat untuk berhasil, sehingga masyarakat menjadi berdaya. (Hasil Wawancara dengan Ibu Rusmiatin Lurah Dadapan)

Kegiatan ini menggerakan masyarakat untuk bermasyarakat dengan cara kerja berkelompok sehingga kesatuan desa semakin baik, selain itu dengan adanya kegiatan itu memberikan manfaat ekonomis bagi masyarakat karena adanya pendapatan tambahan. (Hasil Wawancara dengan Ibu Yati ketua kelompok Perempuan) 


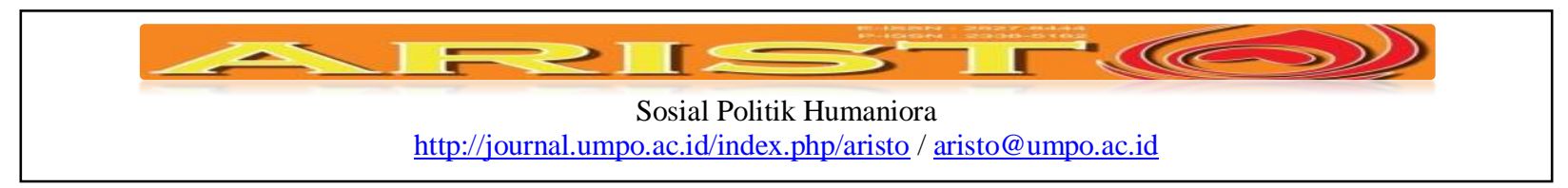

Saya secara pribadi dengan adanya program ini kembali bersemangat karena dahulunya karena status "janda" yang saya sandang, akhirnya ketika berpisah dengan mantan suami, saya mulai kehilangan mata pencaharian dan juga kesulitan dalam memperoleh pekerjaan karena keterbatasan ketrampilan, dengan kegiatan ini saya mendapatkan banyak manfaat, seperti pemahaman, ketrampilan juga kepercayaan diri, tidak hanya itu saya juga mulai mendapatkan penghasilan tambahan dari kegiatan tersebut. (Hasil Wawancara dengan Ibu Sumi Anggota kelompok Perempuan)

Dampak positifnya sangat banyak, saya bisa "guyub rukun", bersama - sama teman saya, yang notebenenya memiliki status yang sama "janda", dan melakukan aktifitas kerajinan dan kesenian yang bisa menguatkan kehidupan kami, yang sudah tidak punya kepala keluarga lagi, sehingga beban kami menjadi semakin ringan. (Hasil Wawancara dengan Ibu Harmi Anggota kelompok Perempuan)

Melihat dampak yang di muncul sebagai efek domino dari kegiatan masyarakat, menjelaskan bahwa, program pemberdayaan ini sangat efektif, sehingga berhasil untuk mencapai targetan yang diinginkan, sasarannya sendiri adalah ibu - ibu masyarkaat Desa Dadapan yang bersatus "janda", hal ini disebabkan karena mereka memiliki banyak keterbatasan dalam menjalankan kehidupan. Keberhasilan ini menandakan bahwa konsep pemberdayaan masyarakat sangat efektif dalam menyelesaikan persoalan - persoalan tentang kemiskinan dan juga kesenjangan.

Pelaksanaan program tersebut, dilakukan melalui beberapa tahapan dan juga proses, mulai dari proses awal yakni: 1). Pemetaan wilayah melalui observasi, setelah itu 2). pendekatan guna memberikan pemahaman kepada masyarakat, terkait program - program yang akan dilakukan, disinilah tahapan terpenting, karena seberapa meyakinkan kita di sinilah akan di uji, setelah kepercayaan di peroleh, maka kemudian dilanjutkan dengan proses, 3). Pelaksanaan program melalui berbagai kegiatan bisa di lakukan, setelah itu baru dilakukan 4). pameran produk hasil yang kemudian bisa memberikan efek domino yaitu, penambahan pendapatan, kekuatan sosial berupa solidaritas dan kesetiakawanan, hingga kemandirian.

Secara umum pelaksanaan program pemberdayaan masyarakat di Desa dadapan melalui kelompok - kelompok dan komunitas, sehingga model komunikasi diatur melalui struktur organisasi. Biasnya kelompok - kelompok tersebut memiliki struktur yang terdiri dari: Ketua, sekretaris, Bendahara, serta Anggota. (Hasil Wawancara dengan Ibu Rusmiatin Lurah Dadapan) 


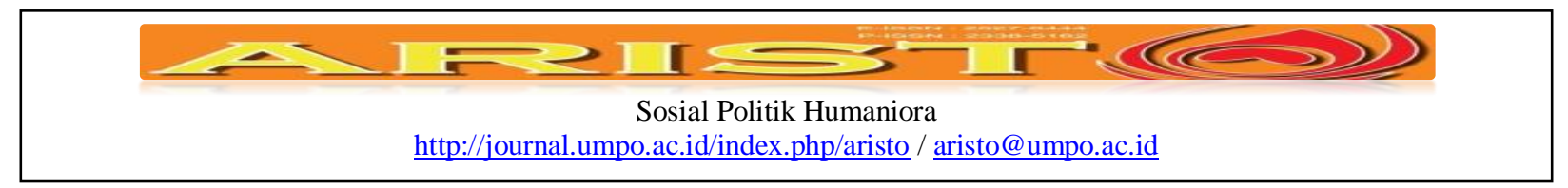

Kegiatan ini dilakukan secara tersetruktur, diawali dengan proses sosialisasi dan pembentukan kelompok kecil, kemudian dalam agenda berikutnya mulai dilakukan pelatihan - pelatihan hingga memiliki ketrampilan yang memadai, setelah itu dilakukan pemasaran produk dan juga mengajari mereka manajemen yang baik, setelah itu proses pendampingan dilakukan terus menerus sampai pada kondisi ibu - ibu tersebut sudah mandiri dan mampu menjalankan kegiatannya. (Hasil Wawancara dengan Ibu Yati ketua kelompok Perempuan)

Prosesnya secara umum, kumpul - kumpul, membentuk kelompok, mulai dari ketua bendahara, sekertaris hingga bendarahara, kemudian dilanjutkan pada pertemuan berikutnya dengan agenda pelatihan - pelatihan ketrampilan, kemudian dilakukan proses menampilkan produk dari program pemberdayaan masyarakat. (Hasil Wawancara dengan Ibu Sumi Anggota kelompok Perempuan)

Prosesnya kumpul - kumpul pelatihan kemudian manajemen hasil program pemberdayaan masyarakat, jadi kegiatannya rutin. Kegiatan pemberdayaan masyarakat yang dilakukan oleh ibu - ibu dilakukan sekitar pukul 14.00 setelah pulang dari lading, dan hari minggu sekitar pukul 10.00 untuk latihan kesenian. (Hasil Wawancara dengan Ibu Harmi Anggota kelompok Perempuan)

Secara umum proses pelaksanaan program pemberdayaan di Desa Dadapan Kecamatan Balong, Kabupaten Ponroogo, dapat di jelaskan melalui 3 (tiga) proses, yakni: 1). Awalan, 2). Proses, 3). Luaran. Untuk mempermudah memahami alur proses pelaksanaan program pemberdayaan masyarakat bisa dilihat dari skema yang kami buat yakni sebagai berikut.

\section{`Gambar 5.6 Skema Program Pemberdayaan Masyarakat}

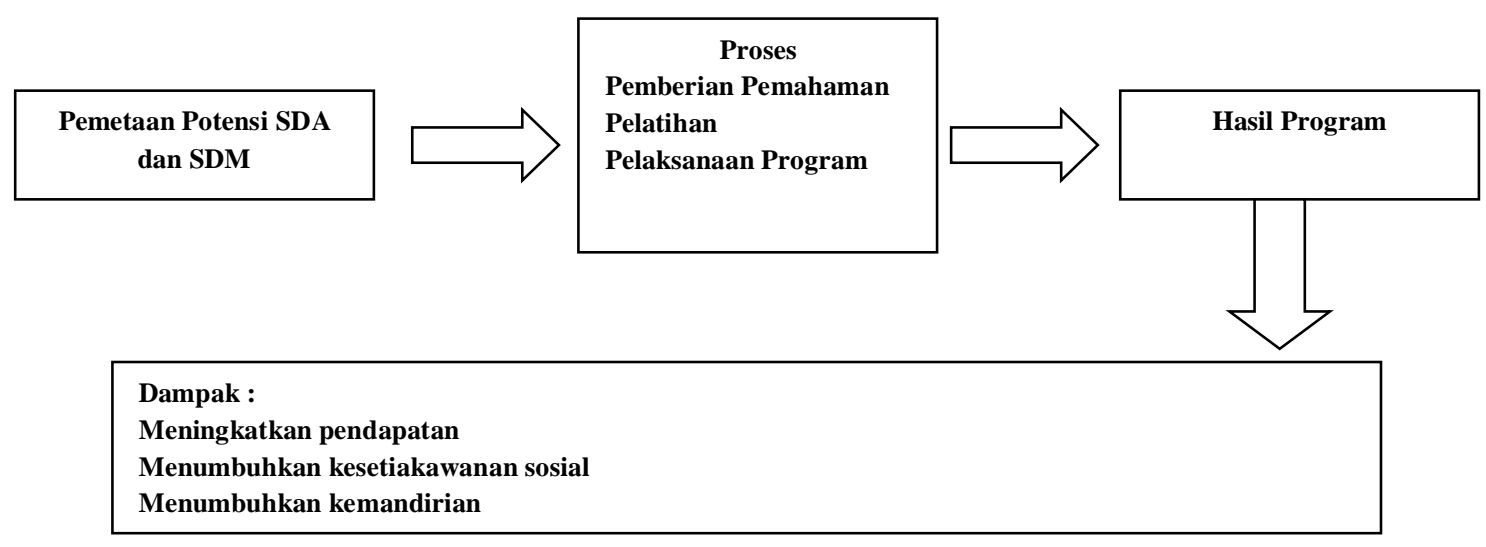

Sumber diolah dari: Data Hasil Penelitian 


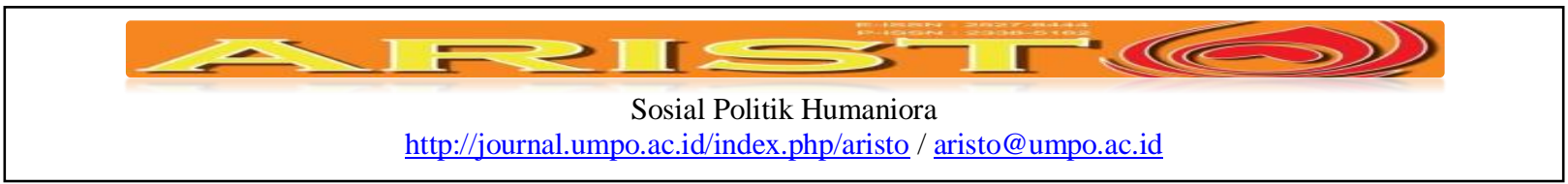

\section{Kesimpulan}

Kegiatan pemberdayaan masyarakat di Desa Dadapan, meliputi 1). Pelatihan pembuatan olahan hasil pangan dari potensi pertanian yang ada, 2). Membuat lumbung dapur dari lahan di sekitar masyarakat. 3). Melatih kegiatan berkesenian ibu - ibu yang berstatus "Janda". Kegiatan pemberdayaan masyarakat di Desa Dadapan, yang telah dilakukan sangat fokus terhadap "janda", telah memberikan kontribusi positif terhadap kehidupan mereka, secara ekonomis, psikologis sehingga anggota kelompok ini menjadi termotivasi dan berdaya. 


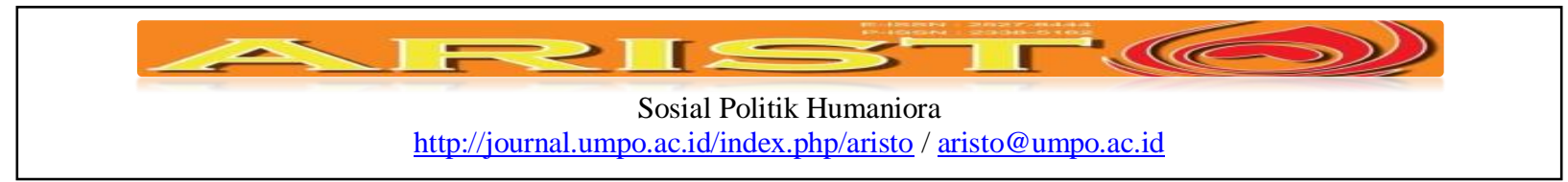

\section{Daftar Pustaka}

Cholisin. (2011, Desember). Pemberdayaan Masyarakat. Disampaikan Pada Gladi Manajemen Pemerintahan Desa Bagi Kepala Bagian/Kepala Urusan Hasil Pengisian Tahun 2011 Di Lingkungan Kabupaten Sleman, 19-20 Desember 2011 , Pp. 19-20.

Desa PM. wong cilik". 2006;(2000):1-21.

Diah, A. (2015). Pembangunan Kemandirian Desa Melalui Konsep Pemberdayaan: Suatu Kajian Dalam Perspektif Sosiologi. Sosio Informa , 175-188

Diakses dari Harian Ponorogopos edisi. No. 725 Tahun XV, 21 - 27 April 2016 pada 27 April 2016

Diakses dari http://bdkpadang.kemenag.go.id/index.php?option=com_content\&view=article\&id=537: persiapan-perkawinan-ditinjau-dari-segi-biologis-dan-psikologis\&catid=41:top-headlines diakses 08 Desember 2018.

Djaelani AR. Teknik Pengumpulan Data Dalam Penelitian Kualitatif. FPTK IKIP Veteran Semarang. 2013:82-92.

Fallis A. No Title No Title. J Chem Inf Model. 2013;53(9):1689-1699. doi:10.1017/CBO9781107415324.004. etheses.uin-malang.ac.id

Hadi AP, Negeri DD. Tinjauan Terhadap Berbagai Program Pemberdayaan Masyarakat di Indonesia. 2001.

Hasil wawancara

Herdiansyah, Haris. 2010. Metodologi Penelitian Kualitatif untuk Ilmu-Ilmu Sosial. Jakarta: Salemba Humanika. www.ejournal.-s1.undip.ac.id

Hidayat, T. (2010, September). Isu-Isu Aktual Penelitian Pemberdayaan Masyarakat. Pp. 1 - 11

I G. W. Murjana Yasa. 2005:86-91

Miles, MB dan AM Huberman. (1992). Qualitative Data Analysis: A Sourcebook of New Methods. SAGE.

Parker L. The theory and context of the stigmatisation of widows and divorcees ( janda ) in Indonesia. Indones Malay World. 2015;44(128):7-26. doi:10.1080/13639811.2015.1100863. 


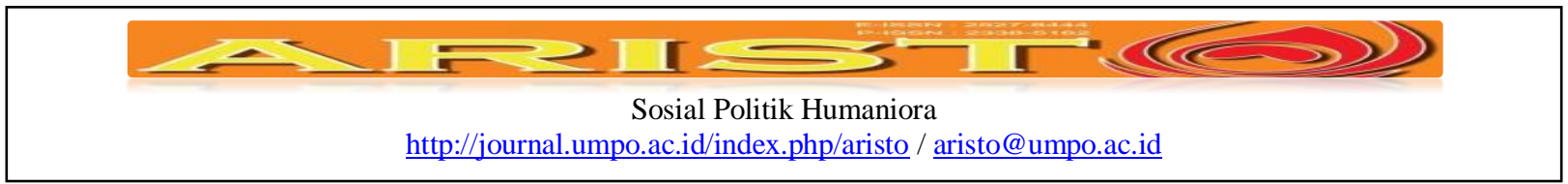

S RWV, Ekonomika F, Bisnis dan, Diponegoro U. Analisis peran ganda dan strategi pemberdayaan janda yang bekerja di kota semarang. 2013.

Setyowati L, Psikologi F, Surakarta UM. Kebermaknaan hidup pada janda. 2014.

Somantri GR. Memahami metode kualitatif. Makara, Sos Hum. 2005;9(2):57-65. http://journal.ui.ac.id/index.php/humanities/article/view/122/118.

Suradisastra K. Farmer’ s Institutional Empowerment Strategy. 2008;26(70):82-91.

Tampubolon J. Pemberdayaan masyarakat melalui pendekatan kelompok. skripsi. 2006.

Widayanti, S. (2012). Pemberdayaan Masyarakat : Pendekatan Teoritis. Welfare Ilmu Kesejahteraan Sosial , 87-102 